\title{
MODEL DAN FORMAT ANALISIS KEBUTUHAN MULTIMEDIA PEMBELAJARAN INTERAKTIF
}

Oleh: M. Miftah *)

\section{Abstrak}

Pembaharuan bidang pendidikan di Indonesia senantiasa dilakukan secara berkesinambungan dan salah satu di antaranya adalah perbaikan dan pengembangan kurikulum. Kurikulum yang diberlakukan dewasa ini adalah Kurikulum Tingkat Satuan Pendidikan (KTSP). Multimedia yang secara sengaja dan kreatif dirancang untuk membantu memecahkan permasalahan pembelajaran, kiranya merupakan alternatif yang akan banyak mengambil peran dalam implementasi KTSP. Berbagai bentuk pengalaman belajar, baik yang dapat dicapai di dalam maupun di luar kelas, pesan-pesan pembelajaran, dan berbagai bentuk pengalaman belajar perlu dikemas dengan memperhatikan kaidah serta prinsip teknologi pembelajaran dalam bentuk multimedia. Agar program multimedia yang dikembangkan sesuai dengan kebutuhan peserta didik, perlu dilakukan analisis kebutuhan. Analisis kebutuhan bertujuan untuk mendapatkan topiktopik yang akan dimultimediakan. Dalam kaitan ini, digunakanlah alur kerja, model, dan format analisis kebutuhan. Metode yang diterapkan adalah dalam bentuk lokakarya yang melibatkan para guru bidang studi, kalangan akademisi, dan para (media, teknologi pembelajaran, teknologi informasi, kurikulum). Hasil kegiatan yang diharapkan adalah model dan format analisis kebutuhan yang digunakan untuk mengidentifikasi topik-topik yang akan dimultimediakan melalui pengkajian kurikulum secara mendalam.

Kata Kunci: model dan format, analisis kebutuhan, multimedia pembelajaran interaktif

\section{A. PENDAHULUAN}

\section{Latar Belakang}

Proses belajar-mengajar atau proses pembelajaran merupakan kegiatan pelaksanaan kurikulum suatu lembaga pendidikan dengan tujuan untuk mempengaruhi para peserta didik mencapai tujuan pendidikan yang telah ditetapkan. Tujuan pendidikan pada dasarnya adalah untuk mengantarkan para peserta didik menuju perubahanperubahan tingkah laku, baik yang bersifat intelektual, moral maupun sosial sehingga dapat hidup mandiri sebagai individu dan makhluk sosial. Dalam rangka mencapai tujuan yang dimaksudkan, peserta didik berinteraksi dengan lingkungan belajar yang dikelola guru melalui proses pembelajaran.

Lingkungan belajar yang dikelola guru mencakup tujuan pembelajaran, bahan pembelajaran, metodologi pembelajaran, dan penilaian pembelajaran. Unsur-unsur inilah yang biasanya dikenal dengan

*) M. Miftah, M.Pd. adalah tenaga pengkajian dan perancangan Balai Pengembangan Multimedia Semarang, Pustekkom, Depdiknas 
komponen-komponen pembelajaran. Tujuan pembelajaran adalah tujuan yang akan dicapai peserta didik pada akhir pembelajaran dengan menempuh berbagai pengalaman belajar. Bahan pembelajaran adalah seperangkat materi keilmuan yang terdiri atas fakta, konsep, prinsip, generalisasi suatu ilmu pengetahuan yang bersumber dari kurikulum dan dapat menunjang tercapainya tujuan pembelajaran. Berbagai metodologi pembelajaran digunakan guru untuk berinteraksi dengan peserta didik, agar bahan pembelajaran yang dirancang guru dapat dipahami peserta didik sesuai dengan tujuan pembelajaran yang ditetapkan.

Berbicara mengenai metodologi pembelajaran berarti ada dua aspek yang paling menonjol yakni metode mengajar dan media pembelajaran sebagai alat bantu mengajar. Sedangkan penilaian adalah alat untuk mengukur atau menentukan tingkat pencapaian tujuan pembelajaran atau penguasaan peserta didik terhadap kompetensi yang ditetapkan guru (Sudjana dan Rivai, 2002). Multimedia pembelajaran interaktif merupakan suatu program yang dapat mengkombinasikan beberapa jenis media, seperti: teks, grafik, suara, animasi, dan video dalam satu aplikasi (program) komputer. Sedangkan menurut Ade Kusnandar, multimedia terdiri dari beberapa unsur media, terintegrasi, kompak, saling mengisi, interaktif, SR, mandiri, dan self explanation (Kusnandar, 2007).

Seiring dengan perkembangan teknologi, diperlukan penyedia media yang mengembangkan program pembelajaran. Hasil riset telah membuktikan bahwa komputer merupakan media penyampaian materi pembelajaran yang efektif (Thompson, 1980). Agar materi pembelajaran yang disajikan melalui komputer sesuai dengan kebutuhan, maka diperlukan adanya analisis kebutuhan. Tujuan melakukan analisis kebutuhan itu sendiri adalah untuk mengetahui topik-topik materi pelajaran yang benar-benar dibutuhkan pengguna, format materi sajian yang dibutuhkan, model sajian materi pelajaran yang efektif, dan topik materi pelajaran yang tepat untuk disajikan melalui program pembelajaran berbasis multimedia.

\section{Permasalahan}

Berdasarkan latar belakang tersebut di atas, maka permasalahan yang akan dibahas di dalam tulisan ini adalah: (a) model dan format analisis kebutuhan MPI yang efektif dan efisien dan (b) prosedur menyusun model dan format analisis kebutuhan MPI.

\section{B. KAJIAN LITERATUR}

\section{Pemahaman akan Konsep}

a. Pengertian Analisis Kebutuhan Analisis kebutuhan merupakan aktivitas ilmiah untuk mengidentifikasi faktor-faktor pendukung dan penghambat (kesenjangan) proses pembelajaran guna memilih dan menentukan media yang tepat dan relevan mencapai tujuan pembelajaran (goals and objectives) yang mengarah pada peningkatan mutu pendidikan. Analisis kebutuhan media pembelajaran dilakukan sebelum suatu media pembelajaran tertentu dirancang dan dikembangkan.

Pada prinsipnya tujuan analisis kebutuhan adalah untuk mengidentifikasi topik dan media pembelajaran yang tepat dan relevan. Uwes Chaeruman mengutip pendapat Brinkerhof \& Gill yang mengatakan bahwa analisis kebutuhan adalah: "a process for identifying the knowledge and skills necessary for achieving organizational goals" (Chaeruman, 2007).

Sedangkan Molenda, Pershing, dan Reigeluth mengemukakan bahwa analisis kebutuhan adalah "a method of finding out the nature and extent of performance problems and how they can be solved" (Molenda, Pershing, 
\& Reigeluth, 1996). Kemudian, Gupta merumuskan pengertian analisis kebutuhan sebagai "a process for pinpointing reasons for gaps in performance or a method for identifying new and future performance needs" (Gupta, 1999).

Pengertian analisis kebutuhan secara umum adalah "a systematic approach to identifying social problems, determining their extent, and accurately defining the target population to be served and the nature of their service needs" (Rossi, Freeman, \& Lipsey, 1998). Secara khusus, Suharsimi Arikunto mengemukakan bahwa yang menjadi pertimbangan dan kajian dalam analisis kebutuhan adalah (1) kurikulum, yang meliputi pemilihan topik dan penjabaran materi, dan (2) silabi, yang meliputi kesulitan materi, pentingnya materi, dan adanya minat khusus (Arikunto, 2007).

Dari pengertian tersebut di atas dapatlah dikemukakan bahwa analisis kebutuhan multimedia pembelajaran interaktif merupakan analisis terhadap (1) tuntutan kurikulum (SKL, SK, KD, indikator), (2) kebutuhan di lapangan, (3) karakteristik sasaran, (4) potensi ICT untuk pemecahan masalah/ kebutuhan pembelajaran, dan (5) kecenderungan perkembangan masa depan.

b. Kurikulum sebagai Alat Bantu Mempermudah Guru

Kurikulum Berbasis Kompetensi (KBK) pada prinsipnya dirancang untuk memudahkan proses pembelajaran. Dengan adanya kurikulum, kita dapat dengan mudah merancang dan merekonstruksi pembelajaran yang bermakna dan menyenangkan bagi anak. Dengan kata lain, situasi pembelajaran yang menyenangkan akan menimbulkan pembelajaran yang bermakna bagi anak. Dalam kaitan ini, kurikulum dimaknai sebagai "kendaraan" untuk mencapai tujuan, yaitu mengembangkan potensi setiap peserta didik (Hamalik, 2007).

Menurut Nasution, kurikulum merupakan alat/sarana/kendaraan yang sangat penting bagi keberhasilan suatu pendidikan. Sebagai kendaraan, kurikulum bukannya dimaksudkan untuk menyeragamkan prosedur dan proses pembelajaran, karena penyeragaman prosedur dan proses mengakibatkan perlakuan yang diskriminatif kepada peserta didik. Prosedur dan proses yang seragam hanya akan memberi peluang dan keuntungan kepada segelintir anak yang dikategorikan "pintar" sebagaimana yang terjadi dalam proses pembelajaran di Indonesia sampai saat ini (Nasution, 2006).

Agar kurikulum tidak membelenggu guru dan tidak menindas siswa, maka dalam implementasinya, kurikulum perlu diterjemahkan sesuai dengan situasi dan kondisi yang ada. Di dalam kurikulum, semua situasi dan kondisi merupakan potensi awal yang harus dipahami. Artinya, kurikulum akan mengakomodasikan segala bentuk keragaman yang ada, baik keragaman potensi individu siswa maupun keberagaman situasi dan kondisi yang mengitari kehidupan siswa sehari-hari. Inilah yang disebut dengan "curriculum for life".

Curriculum for life adalah kurikulum yang dirancang untuk mengoptimalkan pemberdayaan potensi dalam kapasitas seseorang sebagai manusia. Menurut Mauritz Johnson, kurikulum seharusnya tidak dipandang sebagai aktivitas, tetapi difokuskan secara langsung pada berbagai hasil belajar yang diharapkan (intended learning outcomes) (Johnson, 1977). Dalam pengertian ini, kurikulum diposisikan sebagai kerangka berpikir, program, "tools" atau kendaraan menuju hasil belajar yang diharapkan. 
Hasil belajar yang akan dicapai harus dilihat sebagai produk dinamis yang mendorong tumbuh-kembangnya kekuatan dan motivasi pengembangan diri selanjutnya sehingga setiap siswa mampu menghadapi segala kondisi yang dihadapi. Dalam kaitan ini, proses pembelajaran merupakan upaya memberikan pelayanan terhadap semua siswa agar berkembang secara maksimal sesuai dengan potensi yang dimiliki (Zulfikri, 2008).

c. Implementasi Kurikulum

G. Beauchamp mengartikan implementasi kurikulum sebagai "a process of putting the curriculum to work" (Beauchamp, 1975). Kemudian, Fullan sebagaimana dikutip oleh Seller dan Miller mengartikan implementasi kurikulum sebagai "the putting into practice of an idea, program or set of activities which is new to the individual or organization using it" (Seller dan Miller, 1985). Pada dasarnya dapatlah dikatakan bahwa implementasi kurikulum merupakan suatu kegiatan yang bertujuan untuk mewujudkan atau melaksanakan kurikulum (dalam arti rencana tertulis) ke dalam bentuk nyata di kelas, yaitu terjadinya proses transmisi dan transformasi segenap pengalaman belajar kepada peserta didik.

Bagaimana kaitannya dengan pembelajaran berbasis kompetensi (PBK) dalam implementasi Kurikulum Tingkat Satuan Pendidikan (KTSP)? Mengacu pada asumsi bahwa kurikulum dan pembelajaran memiliki kaitan yang erat dan saling menunjang maka pembahasan mengenai model pembelajaran dalam konteks implementasi KTSP tentu tidak bisa dilepaskan dari karakteristik KTSP. Oleh karena itu, apabila karakteristik utama KTSP adalah human competence dan mastery learning, maka model pembelajaran berbasis komputer atau pembelajaran yang berbasis multimedia tentu saja menjadi semakin penting peranannya. Yang lebih penting lagi adalah "seberapa jauh multimedia pembelajaran yang dikembangakan mampu memfasilitasi siswa memperoleh pengalaman belajar yang mencerminkan penguasaan kompetensi-kompetensi yang dituntut kurikulum?"

Implementasi kurikulum dalam pengembangan program multimedia pembelajaran sebaiknya mempertimbangkan prinsip-prinsip perancangan, di antaranya (1) berpusat pada potensi, perkembangan, kebutuhan, dan kepentingan siswa dan lingkungannya, (2) beragam dan terpadu, (3) tanggap terhadap perkembangan ilmu, teknologi dan seni, (4) relevan dengan kebutuhan hidup, (5) menyeluruh dan berkesinambungan, (6) belajar sepanjang hayat, dan (7) seimbang antara kepentingan nasional dan kepentingan daerah. Dalam kaitan ini, Donal P. Ely mengemukakan bahwa suatu kurikulum dirancang lebih dari sekedar pembelajaran atau pelatihan, tetapi mampu mengorganisasikan antara pengetahuan dengan keterampilan hidup yang sesungguhnya di dalam masyarakat nyata (Ely, 1998).

Prinsip-prinsip perancangan tersebut dapat dijadikan pertimbangan dalam perancangan program multimedia dengan mengikuti prinsip-prinsip pengembangan KTSP, yakni: (1) peningkatan iman dan takwa serta akhlak mulia, (2) peningkatan potensi, kecerdasan, dan minat sesuai dengan tingkat perkembangan dan kemampuan siswa, (3) keragaman potensi dan karakteristik daerah dan lingkungan, (4) tuntutan pembangunan daerah dan nasional, (5) tuntutan dunia kerja, (6) perkembangan ilmu, teknologi, dan seni, (7) agama, (8) dinamika perkembangan global, (9) persatuan 
nasional dan nilai-nilai kebangsaan, (10) kondisi sosial budaya masyarakat detempat, (11) kesetaraan jender, dan (12) karakteristik satuan pendidikan.

Selanjutnya, satu hal yang perlu diperhatikan juga adalah prinsipprinsip pembelajaran berbasis $e$ learning, yaitu: (1) sistem pempelajaran yang mengaplikasikan teknologi informasi superhighway, yang dikenal dengan istilah belajar melalui internet, e-learning, online learning, virtual learning, web-based learning, dll, (2) model pembelajaran generasi ketiga yang merupakan perpaduan antara classroom oriented learning dan open space oriented learning, dan (3) model pembelajaran berbasis aneka sumber yang berorientasi pada aktivitas siswa, mengarahkan siwa untuk aktif mencari dan menemukan sendiri informasi yang diperlukan (Haryono, 2009).

\section{Pengantar Pelaksanaan Analisis Kebutuhan MPI}

a. Bentuk Pelaksanaan Analisis Kebutuhan MPI

Analisis kebutuhan dilaksanakan dalam bentuk lokakarya untuk memperoleh data tentang format identifikasi pemilihan topik-topik secara lebih mendetail sesuai dengan kebutuhan dan karakteristik kemediaan yang telah dipilih melalui analisis dari berbagai jurusan dan bidang ilmu. Kegiatan ini melibatkan guru dan dosen. Sistematika perumusan analisis kebutuhan diawali dengan pengarahan dan penjelasan teknis, yang dilanjutkan dengan pengenalan multimedia pembelajaran interaktif online (terhubung dengan internet) dan offline (berbasis CD-ROM). Untuk memberikan gambaran yang jelas di kalangan peserta lokakarya, disajikan contoh program pembelajaran MPI, baik dari produk swasta maupun produk BPM/Pustekkom.

Untuk memperkaya wawasan, disajikan juga materi bahasan tentang karakteristik media pembelajaran, strategi pembelajaran penggunaan media, penelitian yang berhubungan dengan analisis kebutuhan multimedia, implementasi kurikulum KTSP (sosial dan sains) dalam multimedia, praktek pemilihan topiktopik yang akan dimultimediakan, dan diakhiri dengan presentasi/ diskusi panel hasil pemilihan topik-topik sebagai uji empirik.

b. Desain Pelaksanaan Analisis Kebutuhan MPI

Sedangkan skenario atau alur kegiatan analisis kebutuhan multimedia pembelajaran interaktif (MPI) dapat dilihat pada skema berikut ini.

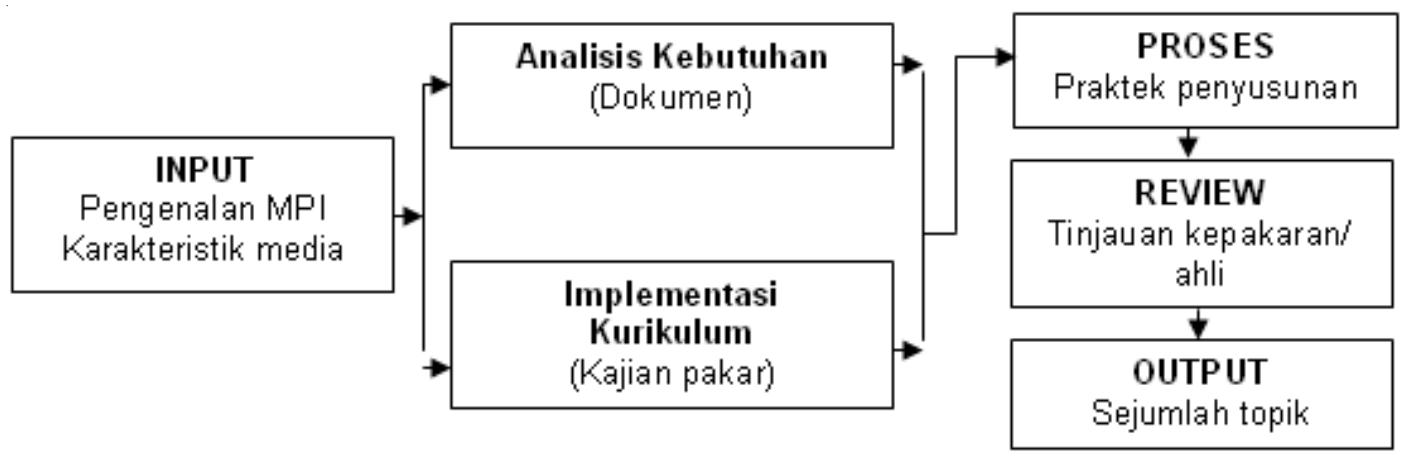

Gambar 1: Desain analisis kebutuhan media pembelajaran 
c. Prosedur Analisis Kebutuhan MPI

Pada Gambar 2 berikut ini disajikan langkah-langkah atau prosedur melakukan analisis kebutuhan multimedia pembelajaran interaktif (MPI).

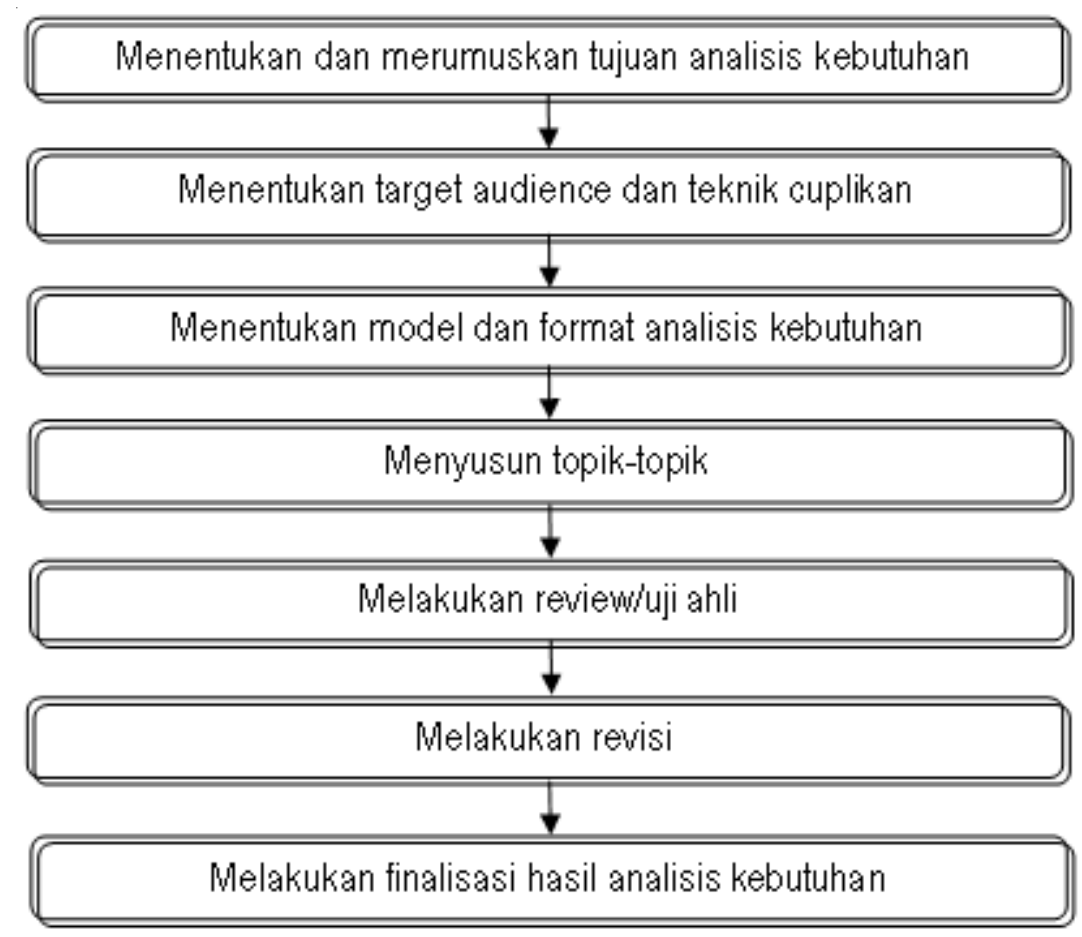

Gambar 2: Prosedur menganalisis kebutuhan multimedia pembelajaran

Sedangkan cara-cara yang ditempuh dalam mengidentifikasi kebutuhan topik multimedia adalah sebagai berikut:

1) menulis standar kompetensi yang ada dalam satu mata pelajaran, dan

2) melakukan analisis dengan cara:

a) menyeleksi kompetensikompetensi dasar yang relevan untuk dimediakan,

b) menentukan kompetensikompetensi program multimedia,

c) menggambarkan hubungan antar kompetensi program media dalam bentuk bagan,

d) memberi nomor setiap kompetensi program media, dimulai dari kompetensi yang paling awal (dimulai dengan nomor 1) secara berurutan sampai dengan kompetensi yang terakhir,

e) memberi tanda panah pada setiap kompetensi dimulai dari kompetensi yang paling rendah ke kompetensi yang lebih tinggi.

3) Menuliskan judul program multimedia berdasarkan kompetensi program media.

4) Menentukan versi/jenis untuk program tertentu, baik online (berbasis web) dan offline (berbasis CD ROM).

5) Menentukan kode program multimedia.

Untuk memudahkan cara menganalisis sebaiknya ditentukan prioritas dan urutan kompetensi yang dapat dilihat pada gambar 3 berikut ini. 


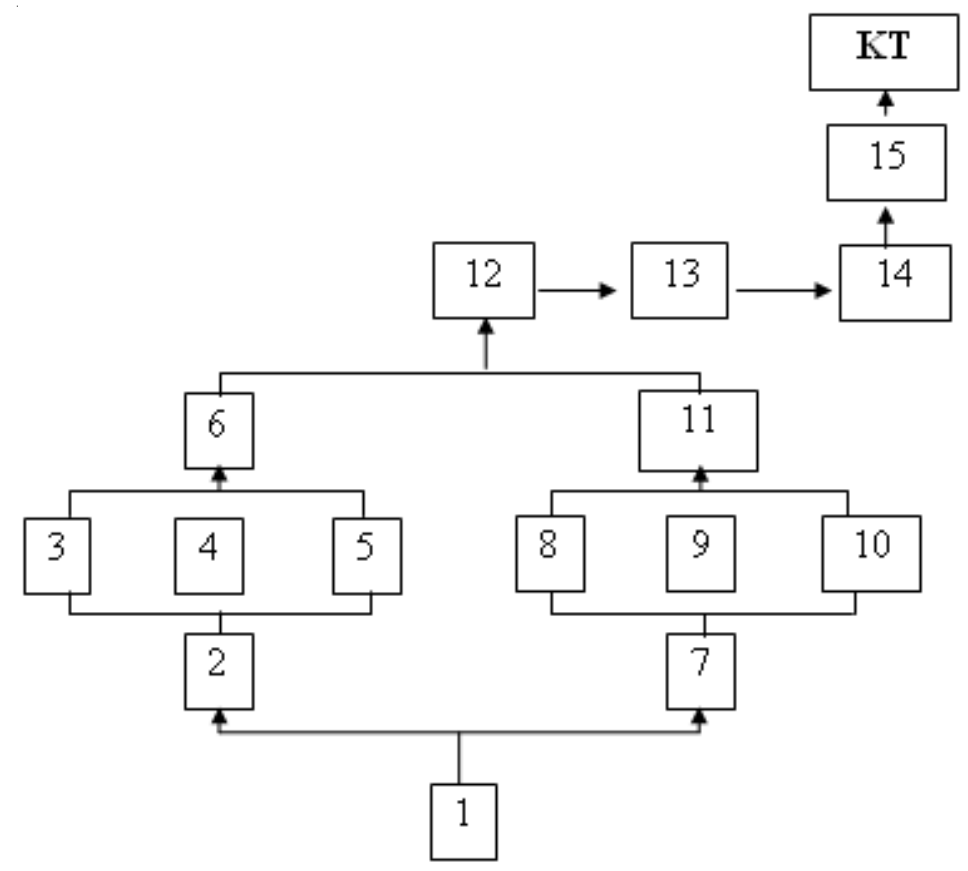

Gambar 3: Penentuan perioritas dan urutan kompetensi

Keterangan:

- KT : Kompetensi Target

- 1, 2, 3, dst. : Kompetensi-kompetensi Program Media

Komponen untuk menyusun format kebutuhan multimedia yaitu: standar kompetensi, kompetensi dasar, kompetensi program multimedia, judul program multimedia, topik, penentuan jenis program, dan kode program multimedia dapat dilihat pada gambar 4 berikut:

\section{Format identifikasi kebutuhan program multimedia}

Satuan Pendidikan

Mata Pelajaran

Kelas/Semester

Standar Kompetensi*)

\begin{tabular}{|c|c|c|c|c|c|}
\hline $\begin{array}{c}\text { Kompetensi } \\
\text { Dasar }\end{array}$ & $\begin{array}{c}\text { Kompetensi } \\
\text { Program Media }\end{array}$ & $\begin{array}{c}\text { Judul } \\
\text { Program } \\
\text { Mledia }\end{array}$ & $\begin{array}{c}\text { Topik } \\
\text { Onlinel } \\
\text { Offline }\end{array}$ & $\begin{array}{c}\text { Kode } \\
\text { Program }\end{array}$ \\
\hline & & & & & \\
\hline & & & & & \\
\hline
\end{tabular}

Gambar 4: Komponen untuk menyusun format kebutuhan multimedia.

d. Pemilihan Kompetensi Target

1) Aspek Kompetensi

Untuk merumuskan aspek-aspek kompetensi secara rinci dapat dilakukan dengan cara menganalisis taksonomi tertentu. Sebagai contoh, misalnya Bloom dkk. menganalisis kompetensi berdasarkan taksonominya menjadi tiga aspek/ranah, yang masing-masing 
disusun secara berjenjang

(Bloom, 1956), yaitu:

a) Kompetensi pada aspek/ ranah kognitif (kecerdasan), meliputi tingkatan pengetahuan, pemahaman, aplikasi, analisis, sintesis, dan evaluasi,

b) Kompetensi pada aspek/ ranah psikomotor (gerak), meliputi keterampilan meniru, memanipulasi, ketepatan gerakan, artikulasi, dan naturalisasi, dan

c) Kompetensi pada aspek/ ranah afektif (perasaan), meliputi pengenalan, pemberian respons, penghargaan terhadap nilai, pengorganisasian, dan internalisasi.

Sedangkan Hall \& Jones membagi kompetensi menjadi 5 macam (Hall \& Jones, 1976), yaitu:

a) Kompetensi kognitif, yang mencakup pengetahuan, pemahaman, dan perhatian.

b) Kompetensi afektif, yang menyangkut nilai, sikap, minat, dan apresiasi.

c) Kompetensi penampilan yang menyangkut demonstrasi keterampilan fisik atau psikomotorik.

d) Kompetensi produk atau konsekuensi yang menyangkut keterampilan melakukan perubahan terhadap pihak lain.

e) Kompetensi eksploratif atau ekspresif, menyangkut pemberian pengalaman yang mempunyai nilai kegunaan di masa depan, sebagai hasil pengiring yang positif.

2) Prinsip Pemilihan Kompetensi Beberapa prinsip yang mendasari pemilihan kompetensi dalam pengembangan multimedia antara lain adalah: ilmiah, memperhatikan perkembangan dan kebutuhan peserta didik, sistematis, relevan, konsisten, dan cukup (adequate).

Prinsip pertama dalam pengembangan multimedia adalah bahwa multimedia disusun berdasarkan prinsip ilmiah. Mengingat multimedia berisikan garis-garis besar isi atau materi pembelajaran yang akan dipelajari oleh peserta didik, maka materi pembelajaran yang disajikan dalam multimedia harus memenuhi kebenaran ilmiah. Untuk mencapai kebenaran ilmiah, maka penyusunan multimedia perlu melibatkan pakar/ahli bidang keilmuan masing-masing mata pelajaran. Hal ini dimaksudkan agar materi pembelajaran yang disajikan dalam multimedia sahih (valid).

Prinsip kedua yang melandasi penyusunan multimedia adalah perkembangan dan kebutuhan peserta didik. Cakupan, kedalaman, tingkat kesukaran, dan urutan penyajian materi dalam multimedia disesuaikan dengan tingkat perkembangan peserta didik. Misalnya materi pembelajaran yang diberikan kepada peserta didik kelas satu berbeda dengan materi yang diberikan kepada peserta didik kelas dua maupun kelas tiga, baik mengenai cakupan dan kedalaman, maupun urutan penyajiannya.

Prinsip ketiga yang melandasi penyusunan multimedia adalah prinsip sistematis. Oleh karena itu, silabus dianggap sebagai sebuah sistem. Sebagai sebuah sistem, multimedia merupakan satu kesatuan yang mempunyai tujuan, yang terdiri dari bagianbagian atau komponen yang satu sama lain saling berhubungan dalam rangka mencapai tujuan. 
Prinsip keempat dalam penyusunan multimedia adalah prinsip relevansi, konsistensi, dan kecukupan antara standar kompetensi dan kompetensi program multimedia. Relevan berarti ada keterkaitan. Konsisten berarti taat asas. Hubungan antara komponen-komponen multimedia harus taat asas. Sedangkan adequate berarti cukup atau memadai. Prinsip adekuasi mensyaratkan agar cakupan atau ruang lingkup materi yang dipelajari peserta didik cukup memadai untuk menunjang tercapainya penguasaan kompetensi dasar yang pada akhirnya membantu tercapainya standar kompetensi.

3) Jenis Kompetensi

Jenis kompetensi yang harus dikuasai ditentukan dengan menyesesuaikan jenis materi sebagai wahana untuk penguasaan kompetensi, apakah berupa: fakta, konsep, prinsip, atau prosedur, dengan ciri masing-masing sebagai berikut:

a) Jenis materi berupa fakta

Kata kunci: Nama, jenis, jumlah. Contoh: Jenis-jenis binatang memamah biak, tanaman berbiji tunggal, nama-nama bulan dalam setahun.

b) Jenis materi berupa konsep Kata kunci: definisi, klasifikasi, identifikasi, ciri-ciri. Contoh: Bujursangkar ialah empat persegi panjang yang keempat sisinya sama panjang

c) Jenis materi berupa prinsip Kata kunci: Hubungan, sebab-akibat, jika....maka... .Contoh: Jika permintaan naik, sedangkan penawaran tetap, maka harga akan naik.

d) Jenis materi berupa prosedur Kata kunci: Langkah-langkah mengerjakan tugas secara urut/prosedural.
Contoh: Cara mengukur suhu badan menggunakan termometer, cara menelepon

Berbagai sumber untuk mengembangkan program multimedia antara lain adalah: (a) kurikulum, (b) buku teks, (c) laporan hasil penelitian, (d) jurnal, majalah, Koran, (e) media audiovisual, internet, (f) pakar bidang studi, (g) professional, dan (h) lingkungan (alam, sosial, seni budaya, industri, kegiatan ekonomi, dll.).

e. Pelaksanaan Analisis Kebutuhan MPI

1) Makna dan Sumber Informasi Kebutuhan

Kebutuhan biasanya dimaknai sebagai kesenjangan antara keadaan yang ada dengan keadaan yang seharusnya. Sedangkan masalah adalah kesenjangan yang besar atau mendesak untuk diatasi/ dipecahkan. Kebutuhan multimedia adalah kebutuhan yang berhubungan dengan aktivitas perancangan, pengembangan, dan pemanfaatan multimedia. Adapun informasi tentang kebutuhan multimedia dapat bersumber dari pendidik/guru, peserta didik, maupun dari masyarakat.

2) Proses Pelaksanaan Analisis Kebutuhan MPI

Kegiatan-kegiatan yang dilakukan dalam menganalisis kebutuhan multimedia pembelajaran interaktif adalah:

a) Menentukan kesenjangan, yang dilakukan dengan cara membandingkan antara kompetensi yang seharusnya dengan kompetensi yang dimiliki (das solen dengan das sein),

b) Menilai signifikansi kesenjangan, yang meliputi penilaian terhadap signifikansi pengaruh, luas 
ruang lingkup, serta peran kebutuhan tersebut terhadap masa depan peserta didik, dan

c) Menetapkan masalah, dengan cara memilih dan memilah kebutuhan mana yang dianggap penting untuk dipecahkan dengan program multimedia.

Pertimbangan dalam menganalisis kebutuhan multimedia pembelajaran di atas untuk jelasnya dapat dilihat gambar 5 berikut

PROSES PEMBELAJARAN

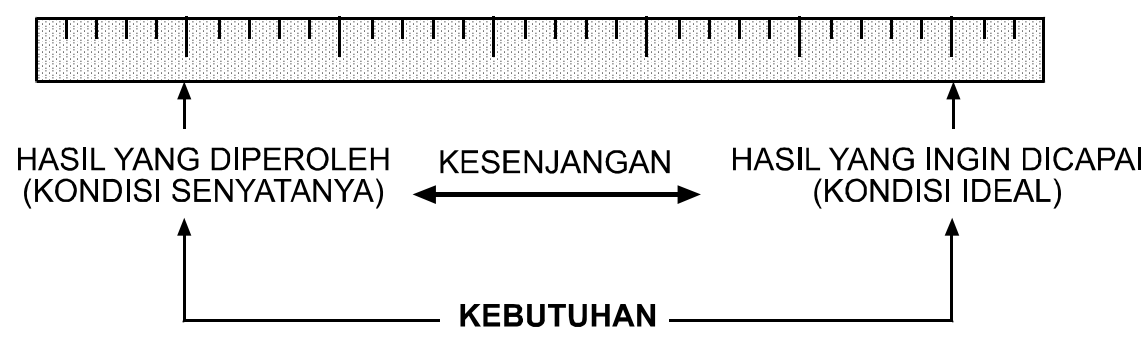

Gambar 5:

Pertimbangan menganalisis kebutuhan media pembelajaran

Kesenjangan dapat disebabkan oleh berbagai faktor, seperti:

- Keterampilan mengajar (teaching skills).

- Media pembelajaran (instructional media).

- Lingkungan belajar (learning environment).

- Iklim belajar (learning climate).

3) Relevansi Model Analisis Kebutuhan

Relevansi analisis kebutuhan multimedia pembelajaran interaktif ini sesuai dengan sirkulasi dan konsep teknologi pembelajaran (Seels, 1994), sebagaimana terlihat dalam gambar 6 berikut ini:

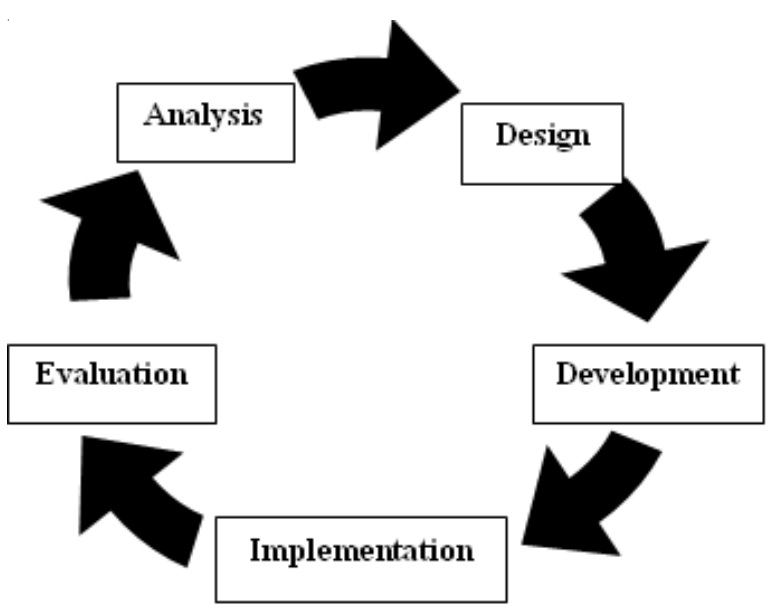

Gambar 6.

Sirkulasi dan Konsep Teknologi Pembelajaran

Sedangkan obyek analisis kebutuhan biasanya berbeda-beda tergantung kebutuhan dan tujuan, sebagaimana dapat dilihat dalam gambar 7 berikut: 
Kurikulum

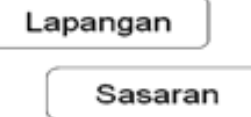

Kebijakan

Trend, Perkembangan

Gambar 7: Obyek Analisis Kebutuhan

\section{SIMPULAN DAN SARAN}

\section{Simpulan}

Pertimbangan dalam merumuskan langkah-langkah atau prosedur melakukan analisis kebutuhan adalah: (a) menentukan dan merumuskan tujuan analisis kebutuhan, (b) menentukan target audience dan teknik cuplikan, (c) menentukan model dan format analisis kebutuhan, (d) menyusun topik-topik, (e) melakukan review/uji ahli, (f) melakukan revisi, sekaligus menganalisis kesalahan format dan kebutuhan topik yang lebih diperlukan oleh sasaran didik/peserta didik, dan (g) finalisasi dan pemanfaatan hasil analisis kebutuhan, tidak terbatas pada format yang dihasilkan lewat analisis kebutuhan, namun bisa dikembangkan komponen-komponennya melalui kegiatan lokakarya lain seperti; model dan format sajian MPI, peta konsep dan peta materi, perumusan garis-garis besar isi media (GBIM), dan jabaran materi.

Proses menganalisis kebutuhan multimedia adalah dengan: (a) menentukan kesenjangan, yang dilakukan dengan cara membandingkan antara kompetensi yang seharusnya dengan kompetensi yang dimiliki (das solen dengan das sein), (b) menilai signifikansi kesenjangan, yang meliputi penilaian terhadap signifikansi pengaruh, luas ruang lingkup, serta peran kebutuhan tersebut terhadap masa depan peserta didik, dan (c) menetapkan masalah, dengan cara memilih dan memilah kebutuhan mana yang dianggap penting untuk dipecahkan dengan program multimedia.

\section{Saran}

Untuk keberhasilan pengembangan dan pemanfaatan multimedia pembelajaran interaktif, khususnya yang terkait dengan implementasi KTSP disarankan agar semua pihak, baik yang berkiprah di bidang pengembangan maupun di bidang pemanfaatan memiliki komitmen untuk memanfaatkan multimedia pembelajaran, memahami peran dan fungsi multimedia secara benar, dan memiliki dokumen pendukung yang memadai.

Pengemasan berbagai bentuk pengalaman belajar, baik yang dapat dicapai di dalam maupun di luar kelas, maupun pesan-pesan pembelajaran, disarankan agar dilakukan dengan memperhatikan kaidah serta prinsip teknologi pembelajaran dalam bentuk multimedia sehingga sesuai dengan kebutuhan peserta didik.

\section{DAFTAR PUSTAKA}

Arikunto, Suharsimi. (2007). Penyusunan Instrumen untuk Analisis Kebutuhan Online dan Offline. Disampaikan dalam kegiatan lokakarya penyusunan instrumen analisis kebutuhan MPI 2007 pada tanggal 27 Maret 2007. Semarang: BPM Semarang

Beauchamp, G. (1975). Curriculum Theory. Willmette, Illionis: The Kagg Press.

Dick, Walter, Lou Carrey and James O. Carey. (2005). The Systematic Design of Instruction. Boston: Pearson, Allyn and Bacon.

Kusnandar, Ade. (2007). Analisis Kebutuhan Multimedia Pembelajaran Interaktif. Disampaikan dalam kegiatan lokakarya penyusunan instrumen analisis kebutuhan MPI 2007 pada tanggal 27 Maret 2007. Semarang: BPM Semarang.

Mukminan. (2008). Menganalisis Kebutuhan Multimedia. Disampaikan dalam Kegiatan Analisis Kebutuhan MPI 2007 pada tanggal 18 Februari 2008. Semarang: BPM Semarang.

Sudjana, Nana dan Rivai, Ahmad. (2002). Media Pengajaran. Bandung: Sinar Baru Algensindo.

Seels, Barbara, B. (1994). Instructional Technology: The definition and domains 
of the field. Washington DC: Association For Educational Communications and Technology.

Seller dan Miller. (1985). Curriculum; Perspectives and Practice. New York: Longman.

Thompson, B.J. 1980. Computers in Reading: A Review of Application and Implications. Educational Technology. XX (8): 38-41

Charumen, Uwes. (2007). Analisis Kebutuhan
Multimedia Pembelajaran. Disampaikan dalam kegiatan lokakarya penyusunan instrumen analisis kebutuhan MPI 2007 pada tanggal 27 Maret 2007. Semarang: BPM Semarang.

Zulfikri. (2008). Menciptakan Layanan terhadap Peserta Didik dalam Upaya Membangun Karakter Setiap Individu Peserta didik. Disampaikan dalam kegiatan analisis kebutuhan MPI 2008 pada tanggal 18 Februari 2008. Semarang: BPM Semarang.

unuuuuuuuuuud 